\title{
CORPORATE GOVERNANCE EFFECTIVENESS AND VALUE ADded at SOUTH AfRican Higher Education INSTITUTIONS: A REGISTRAR'S VIEW
}

\author{
Karin Barac* \\ University of South Africa \\ barack@unisa.ac.za
}

\author{
Ben Marx" \\ University of Johannesburg \\ benm@uj.ac.za
}

May 2012

\begin{abstract}
Higher education institutions are faced with many challenges in fulfilling their core mandate of teaching, research and community engagement. To achieve this, strong, sound and visionary institutional leadership is required, which should be embedded in sound corporate governance practices. The study aims to ascertain what registrars' views on the effectiveness and value added by current corporate governance practices of higher education institutions (HEIs) in South Africa are. This was done through a literature review and supported by empirical evidence obtained from questionnaires addressed to registrars of public $\mathrm{HEls}$ in South Africa, as well as follow up interviews held with participants. The study found strong support for sound corporate governance practices at $\mathrm{HEls}$ in South Africa, and also indicates that these institutions are complying with and adhering to this, although room for improvement exists in certain areas. The value added to and contributions to corporate governance effectiveness by student representative council members and institutional forums were also investigated, and it was found that the evolving corporate governance role of the registrar, over and above the traditional academic and student affairs responsibilities, enjoyed much support. Additional reporting responsibilities, in accordance with current corporate governance developments, were identified as areas not meeting expectations.
\end{abstract}

\section{Keywords}

Corporate governance; higher education; higher education institutions; university councils; university registrar; higher education governance

\footnotetext{
*Prof Karin Barac is professor and head of the Department of Auditing, University of Pretoria, South Africa.

\#Prof Ben Marx is professor and head of Auditing, Department of Accountancy, University of Johannesburg, South Africa.
} 


\section{INTRODUCTION}

Institutions of higher education fulfil a critical role in society by encouraging the dissemination, advancement, development and application of knowledge informed by free inquiry (Nagy \& Robb, 2008:1417). This is done against the background of an increasingly demanding society, limitations on state funding available for tertiary education and greater complexity in higher education governance, which require flexible teaching and learning, corporatisation, commercialism, privatisation as well as increased competition (Boyce, 2002:593). In response, governments in recent years have sought to align accountability and control over higher education by delegating to higher education institutions ( $\mathrm{HEls}$ ) increased authority over their inputs and resource use, while demanding institutional accountability for outputs and performance (Hall, Symes \& Luescher, 2002:15). This deregulation has resulted in a shift in universities: from being state agencies subject to centralised laws and regulations governing budgets, facilities and personnel, they are increasingly becoming public corporations (Dill, 2001: 21-22).

An additional onus is placed on the HEls in South Africa to play a critical role in restoring imbalances from the apartheid era (Kulati, 2000:178). According to the Ministerial Statement of Higher Education Funding (2006/7 to 2008/9) (MoE, 2006) HEls should make major contributions to the social transformation of South African society and stimulate national economic growth and development. Through their student admissions, teaching and learning activities, HEls can assist with the creation of a fairer and more just society for South Africa (MoE, 2006) and, thereby, actively participate in the Accelerated and Shared Growth Initiative for South Africa (ASGISA), which stresses a stronger focus on middle- and high-level skills development in order to ensure that an economic growth target of $6 \%$ between 2010 and 2014 is achieved (PWC, 2009:1; MoE, 2006). These challenges require sound management, effective leadership, and strong governance structures (Bargh, Scott \& Smith, 1996:2-3; Geuna \& Muscio, 2009:94 \& 108; Kezar \& Eckel, 2004:371-372; Marx, 2007:106 \& 120).

This increased focus on the governance of $\mathrm{HEls}$ has changed the roles of senior professional administrators (such as vice-chancellors and registrars) in HEls (Lockwood, 1979:299; Whitchurch, 2004:280). The role of registrar of an $\mathrm{HEl}$, as one of the oldest positions in higher education (Anonymous, 2010; Diamond \& DeBlois, 2007), has evolved in recent years into something resembling a 'company secretary' of an $\mathrm{HEI}$ (IOD, 2009:43). The importance of a registrar in an HEl's governance mechanism is reflected in the Higher Education Act (RSA, 1997: sec. 2, 11, 23, 26 \& 27) of South Africa, which deems him/her to form part of the senior management of South African $H \varepsilon l s$, being a member of senate, serving on its executive committee, and acting as the secretary of council and its committees and senate (RSA, 1997:sec. 23, 26 \& 27). As a member and secretary of the HEl's management committee and the extended management committee (RSA, 1997:sec. 53 \& 54), the registrar is involved in day-today decision-making at executive level. This pivotal role of a registrar in the corporate governance of South African HEls ideally positions him/her to comment on the effectiveness of corporate governance practices and the value they add.

Existing research into the governance practices of $\mathrm{HEls}$ in South Africa has ignored the effectiveness and value added by current practices. Some studies (Van Niekerk, 2005; Kulati, 2000 \& 2003) have investigated leadership in and transformation of South African HEls, and others (Leo, 2003; Naidoo, 2006) have investigated financial performance and related measurement of such institutions, while Hutton (1999) developed a model of HEls' performance 
indicators. Marx (2007:16) benchmarked basic governance-regulatory requirements of South African HEls against corporate governance principles and practices and concluded that although HEls' councils appear to be well-established, their corporate governance disclosures need to be improved. Arnold (2006:65) focused attention on the reporting of South African HEls by researching university sustainability through decision-orientated financial reporting and found that financial reports constitute the major medium of financial accountability through which $\mathrm{HEls}$ render an account of their performance in fulfilment of their responsibilities. Although Kulati (2003:15) asserts that representative governance structures have been accomplished at most South African $\mathrm{HEls}$, whether such structures operate effectively and add value is still open to question. This article attempts to find an answer to these questions by gaining the views of HEls' registrars and, thereby, adding to the limited existing body of knowledge regarding corporate governance at South African HEls.

\section{OBJECTIVES, SIGNIFICANCE AND LIMITATIONS}

\subsection{Research objective}

The purpose of this article is to explore the effectiveness of South African HEls' current corporate governance practices and their value added as perceived by the registrars of these $\mathrm{HEls}$. For the purposes of this study, effectiveness is understood as 'producing or being able to produce the desired effect', while value added is deemed to be to 'recognize the worth, quality or importance' of something (Pearsall, 2002:456 \& 1584). This study is based on the views of registrars of South African $\mathrm{HEls}$ who are not only critical role players in the academic and student affairs of these organisations, but are also regarded as important corporate governance mechanisms of $\mathrm{HEls}$.

\subsection{Significance}

Given the challenges $\mathrm{HEls}$ are facing and the critical role they are playing in providing society with the skilled human resources that are needed for economies to grow, it is essential that these institutions are functioning effectively. Sound corporate governance practices at these institutions are accordingly critical to ensuring the effective functioning of these institutions. For this reason, research contributing to the debate on corporate governance practices of $H E l s$ is essential. Very little research to date has explored South African HEls' corporate governance practices, their effectiveness and value added. This study aims to fill this gap and provide a foundation on which further research can build. Not only is the study exploring current HEls' corporate governance practices, but it also aims to investigate their effectiveness and value added. Areas for improvement are identified and recommendations are made. All levels of management of $\mathrm{HEls}$, government policy makers, funding agencies, potential investors in university projects, stakeholders involved in university community engagement projects, university staff and students could all, directly or indirectly, benefit from the study. Its results could inform future South African HEls' corporate governance practices, thereby contributing to the more effective management of HEls in South Africa.

\subsection{Limitations}

The study has specific limitations in that it is limited to the views expressed by the participating registrars of the $23 \mathrm{HEls}$ in South Africa, which are open to bias and interpretation. A further 
limitation of the study is that not all the registrars of the 23 South African HEls participated in the research: only 17 responded, and, therefore, the results of the study should not be generalised and should be considered against the background of the limitations sketched above. Despite these limitations, this study provides a South African perspective regarding corporate governance at $\mathrm{HEls}$ and makes a contribution to the limited body of knowledge that exists in this regard. The study could also serve as a foundation for further studies to build on.

The remainder of this article is arranged as follows: the next section presents a theoretical background by providing an overview of governance developments in higher education, with an emphasis on the South African perspective. Then the methodology followed in this study is outlined, and this is followed by a section reporting on the findings of the views expressed by the participating registrars of the 23 South African HEls. In the final section the results are summarised, conclusions are made and recommendations for further research are presented.

\section{THEORETICAL FRAMEWORK}

\subsection{Higher education governance}

Institutions of higher education are unique entities with an extraordinary character, which has been described as 'a mediaeval corporation: that is to say, a private association recognised by the state as pursuing a public purpose' (De Groof, Neave \& Svec, 1998:Foreword). An apparent contradiction of this sort means that it is difficult to balance autonomy and accountability, especially where higher education is provided largely through public money, affects the interests of multiple stakeholders in society and should, therefore, be called to public account (Henkel, 1997:134).

Traditionally, universities or $\mathrm{HEls}$ were governed by means of the collegial model, embodying the philosophy of self-governance with little or no direct government interference (Harman \& Treadgold, 2007:13). The view that the supreme authority, providing that it is exercised responsibly, must rest with academics sufficiently qualified to regulate the public affairs of scholars, was well supported (Shattock, 2002:236). However, over the last few decades there has been a move away from this collegial self-governance model to a model more closely aligned with business corporations (Lazaretti \& Tavoletti, 2006:26). The initial paradigm for managing $\mathrm{HEls}$ by means of state policy-making and implementation has been extended to include a more cooperative method of governing (Enders, 2004:372), which according to Mok (2003:119) has changed the role of $\mathrm{HEls}$, which now act less as critics of society and more as servants responding to the needs of society.

This change has been brought about by the many challenges $H E l s$ of today are facing, which include greater levels of accountability, decreased state funding, increased cost of higher education, poorly prepared students, lack of institutional capacity, transformation of students and staff, quality assurance in research and tuition, globalisation, rapid development of information technology, the quest for market orientation and customer-centred operations, increasingly complex legal environments as well as increased competition from local and international providers of private higher education (Brown, 2001: 44-46; CHE, 2009a:2, 6; CHE, 2009b:3 ;De Groof et al., 1998:1; Kezar \& Eckel 2004:371; Marx 2007:108-110; Mills 2007:162; Peterson 1986:6; Pope, 2004:78;83; RSA, 2007:17; Salter \& Tapper, 2002: 245-246; Smout \& Stephenson, 2002: 197-198). The high demands of various stakeholders, including students, employers, teaching and non-teaching staff, government and its funding agencies, accreditors, 
validators, auditors, assessors and professional bodies, further complicate matters (CHE, $2009 \mathrm{c}: 81-84$ ). The resulting shift from an 'easy administration' and collegiality to the need for governance and management of $\mathrm{HEls}$ (Dearlove, 2002:257) is accordingly evident worldwide. According to Geuna and Muscio (2009:93-95), this tendency started in the United Kingdom, and spread to Europe, beginning with the Netherlands and the Scandinavian countries, and more recently to countries such as France and Italy. They found that universities have been transformed from small, elite institutions, managed by academic peers in a collegial way, into large multi-task organisations, and that this requires new governance structures to manage all the tasks and roles of today's institutions (Geuna \& Muscio, 2009:94). By adopting the operational structures of economy, efficiency and performance many universities are behaving like and being run as though they were businesses (Nagy \& Robb, 2008:1414).

An extensive body of knowledge exists on the reforming of higher education to promote transparency and accountability. The idea of a university as a corporate enterprise has become well-established in England, where entrepreneurial universities emerged with strong institutional management (Taylor, 2003:101). Similarly, Australia's higher educational landscape underwent changes as 'executive-centred governance' emerged (Considine, 2000:148-153). Structures to increase state control in the United States higher education system are also visible, although a uniform approach has not been followed: some states are opting for more centralised organisations, while others are attempting to decentralise their systems (Mills, 2007:162-164). As HEls in France are moving towards increased autonomy, they too are subjected to more frequent government monitoring (Belloc, 2003:23; Huisman \& Currie, 2004:55).

\subsection{A South African perspective}

Changes in the relationship between state, society and $H E l$ s, coupled with legislative changes, have transformed the governance of South African HEls. The latter have been brought more in line with other organisations, positioning them for global success through the requirement to demonstrate efficiency, effectiveness and value for money through the integrated use of public finance management accounting systems, external quality assurance systems and other accountability frameworks designed to allow for greater stakeholder scrutiny (Ferreira, 2003:3).

Early higher education institutions in South Africa were based on models from United Kingdom and Scottish universities (Hall et al., 2002). These $\mathrm{HEls}$ were subjected to many political and socio-cultural issues and developments over the years, and these played a role in the formation and structuring of the South African higher education landscape. Another factor that had a significant influence was early dissension about the medium of instruction, which led to a split between English-and Afrikaans-medium universities. This was followed by sharp divisions along racial and ethnic lines, with the $36 \mathrm{HEls}$ being divided into sub-categories, namely the four English-medium universities reserved for white students, the six Afrikaans-medium universities reserved for white students, the seven technikons reserved for white students, the six universities and five technikons located in apartheid homelands and reserved for African students, the two urban universities and two technikons reserved for Coloured and Indian students, the two 'special-purpose' institutions reserved for black students and the two distance-education providers (Hall et al., 2002:20). According to Kulati (2000:186), the historically Afrikaans universities were characterised by highly centralised and autocratic management practices, while many of the English-speaking universities had strong collegial traditions, in which university management was characterised by more participative decision- 
making processes. It is obvious that these divisions made for the unique system that was inherited by the first democratically elected South African government in 1994.

Since 1994, however, the trend has been to realign and reintegrate the South African higher education institutions in line with their global counterparts, and this has been done partly by way of introducing a new governance framework based on the principle of cooperative governance (Kulati, 2003:14). This initiative triggered an avalanche of reports and legislation, such as The Green Paper on Higher Education Transformation, 1996; A Programme for the Transformation of Higher Education 1997; Higher Education Act 101 of 1997; National Plan for Higher Education 2001; The Regulations and Manual for Annual Reporting of Higher Education Institutions 2001, 2003 and 2007; and Research and Policy Report on Governance in South African Higher Education 2002 (Marx, 2007:107-108; Wolhurter, Van der Walt, Higgs \& Higgs, 2007: 501-506). The objective of restructuring the higher education landscape was to achieve an integrated, unified higher education system based on the principles of equity, democratisation, quality, academic freedom, institutional autonomy, effectiveness and efficiency (CHE, 2000; Smout \& Stephenson, 2002:199). The aim was to introduce cooperative governance, shifting HEls from being managed largely through administrative fiat to more managerial and entrepreneurial approaches to leadership (Kulati, 2003:14 \& 15). The latter are in accordance with the objectives of The National Plan for Higher Education: human resource development, high-level skills training and the production, acquisition and application of new knowledge (CHE, 2009a: 3). A new department responsible for higher education (Department of Higher Education and Training (DoHET)) was created by parliament in 2009 to assist $\mathrm{HEls}$ to redefine their role and to look for mechanisms that would support diversity, appropriate governance, funding and quality assurance (CHE, 2009a:1-2).

HEls in South Africa are regulated by the Higher Education Act 101 of 1997 (RSA, 1997), the Regulations of the Act of 2003 and 2007 (RSA, 2003 \& 2007) and the Implementation Manual for Annual Reporting by Higher Education Institutions (hereafter referred to as the reporting manual) issued by the Department of Education (DOE) under the regulations of the Act (DOE, 2007). South African HEls are governed by their respective councils, subject to the Higher Education Act and their own institutional statutes (Hall et al., 2002:36; RSA, 1997). The main governance structures are the council, the senate and the institutional forum. Councils are their highest decision-making body, the supreme governing bodies of $\mathrm{HEls}$, and are responsible for ensuring good governance, quality, integrity, financial soundness, and the performance and reputation of each institution. They have to ensure that the $\mathrm{HEl}$ is financially sound and that executive management carries out its functions responsibly and effectively (Kulati, 2000:179). The council structure is determined by section 27 of the Higher Education Act, with various committees of council elected under section 29 (RSA, 1997). These include, inter alia, audit, remuneration, human resources and finance committees (Hall et al., 2002:120-122; RSA, 1997:sec 21). The institutional forum (RSA, 1997:sec. 38) advises council broadly on issues affecting the institution. It specifically directs its attention to the areas of implementation of legislation and national policy; race and gender equity; the selection of candidates for senior management positions; codes of conduct, mediation and dispute resolution; and the fostering of an institutional culture (Hall et al., 2002:20:37-38). Kulati (2003:14 \& 2000:182) believes that these forums broaden participation in institutional governance and are meant to 'act as shock absorbers to the transformation process', but that many of them struggle to define the role they ought to play in deepening institutional transformation.

A further key governance component of $\mathrm{HEls}$ is the senate, with its subsidiary structures, of which the principal is the faculty boards. Senate is accountable to council for the academic and 
research functions of the $\mathrm{HEl}$, and must also perform other functions delegated to it by council (RSA, 1997:sec. 22; Hall et al., 2002:20). The institutional statute determines that the principal (vice-chancellor and rector) is the CEO of the $H \varepsilon l$ and responsible for the day-to-day management and administration of the HEl (Hall et al., 2002:36; Marx, 2007:112-113; PWC, 2009:6-8).

\subsection{The role of the registrar}

The role of the registrar of an $\mathrm{HEl}$ is one of the oldest positions in higher education (Diamond \& DeBlois, 2007; Anonymous, 2010). Key aspects of a registrar's function include oversight and coordination of the validation and approval of new programmes, quality assurance and enhancement, admissions, enrolments, the organisation of examinations and conferring of awards, graduation ceremonies, student records and support systems, and the maintenance and development of academic regulations, policies and procedures (Anonymous, 2010; Brookes, 2010). In addition, the registrar plays an important role in assuring inclusivity (a sense of belonging) and promoting diversity within an $\mathrm{HEI}$ (Rees, 2009:158).

Over the years the role of the registrar has evolved into a key position in academic innovation and corporate governance at HEls (Anonymous, 2010; Diamond \& DeBlois, 2007; Pelham, Preswood \& Roof, n.d.). Lockwood (1979:308 \& 309) ascribes it to the multiple dimensions of the position, including a secretarial function, administrative function and management function. In many respects the registrar can be regarded as the 'company secretary' of an $\mathrm{HEl}$ by assisting in induction of new council members, providing guidance to council members regarding their duties and responsibilities, providing a central source of guidance and advice to council and the institution on matters of good governance and legislation, as well as keeping minutes of meetings and further ensuring that the $\mathrm{HEI}$ council and its committee charters and terms of references are kept up to date (IoD, 2009: 43-44). This is in line with the requirements of King III, also applicable to $\mathrm{HEls}$, which expect a company secretary to function as an important corporate governance mechanism (IoD, 2009:43-44).

The importance of a registrar in an HEl's governance mechanism is reflected in the Higher Education Act (RSA, 1997: sec. 2, 11, 23, 26 \& 27) of South Africa, which deems him/her to form part of the senior management of South African HEls, being a member of senate, serving on its executive committee, and acting as the secretary of council, and of its committees and senate (RSA, 1997:sec. 23, 26 \& 27). As a member and secretary of the HEl's management committee and the extended management committee (RSA, 1997:sec. 53 \& 54), the registrar is involved in the day-to-day decision-making at executive level. This pivotal role of a registrar in the corporate governance of South African HEls ideally positions him/her to comment on the effectiveness of corporate governance practices and the value they add.

Very little research has been done on the governance of South African HEls and none is based on the perceptions of registrars. In 2000 Kulati (2000:181) explored the then emerging approaches to governance in these institutions and questioned $\mathrm{HEl}$ structures in terms of the 1997 legislation by claiming 'it is doubtful whether there have been radical and fundamental changes'. He further asserts (2000:181 \& 182) that students of these HEls have challenged the role of councils as primary governance bodies and they, as well as worker representatives, feel hindered from participating meaningfully in institutional governance. According to him (2000:182) much support exists for institutional forums, not merely to serve in an advisory function, but to become alternative policy-making structures. This study attempts to contribute to this debate by obtaining the views of HEls' registrars, who are well positioned to observe the 
effectiveness of corporate governance practices and the value they add, but who are not in control of the primary governance structures (council, senate and institutional forum) of South African HEls.

\section{RESEARCH METHODOLOGY}

A mixed method approach was followed, including elements of both quantitative and qualitative research. As quantitative research, an empirical study was conducted by means of questionnaires directed at the registrars of the 23 South African $\mathrm{HEls}$, while the qualitative element of the study consisted of follow-up interviews held with some of the participants. The questionnaire used during this research included open-ended questions, which allowed responding registrars to provide their views, make recommendations and to raise their concerns. Such views, recommendations and concerns form the basis of the follow-up interviews.

Both elements, quantitative and qualitative, aimed at obtaining the views of university registrars on corporate governance practices at their $\mathrm{HEls}$. The quantitative research was directed to determine such views, while the qualitative element of the research focused on illumination and understanding them (Golafshani, 2003:600).

As discussed in section 3.3, the registrar fulfils a critical corporate governance role in an $\mathrm{HEl}$ and is accordingly well positioned to comment on the effectiveness of HEls' corporate governance practices and the value they add. The meanings of the terms effectiveness and value added were disclosed to participants. The registrars' views were obtained through questionnaires, which were distributed in hard copy to them at the Registrars' Imbizo held on 10 and 11 March 2011 in Gauteng. Initially ten registrars responded. The remaining registrars were again requested to participate in the study during March and April 2011 through reminders and questionnaires sent by email. In all instances the questionnaires (in hard copy or email format) were accompanied by a covering letter from the researchers, emphasising the importance of their views for the research and highlighting the anonymity and confidentiality of their responses.

The questionnaire made provision for open-ended questions, thus allowing for descriptive responses, and thus also focusing on the quality of information obtained rather than merely considering its quantitative nature. Such an approach is supported by Henning, Van Rensburg and Smit (2004:3), who stress the importance of capturing the views of the subjects in the population. Questions, other than the open-ended ones, followed a five-point Likert category scale with the options of agreeing: 'not at all' to agreeing 'very much'. An option of ' $n / a$ ' was also provided for respondents to tick if they felt that the question, or an aspect of it, was not applicable.

One of the participating registrars invited the researchers to an in-depth discussion of corporate governance of $\mathrm{HEls}$. The researchers held two extensive interviews with the participant, which forms the qualitative element of the study. Another participating registrar expressed serious reservations about the applicability of corporate governance practices to higher education, and provided detailed comments on the questionnaire. These, together with the other responses received to the open-ended questions in the questionnaire, are of qualitative nature and are included in the discussion of the results of the study in section 5. 


\subsection{Questionnaire design and control}

The questionnaires were developed by taking into account the requirements and recommendations for best practice of the Higher Education Act 101 of 1997 (RSA, 1997), the Regulations of the Act of 2003 and 2007 (RSA, 2003; 2007), the Implementation Manual for Annual Reporting by Higher Education Institutions issued by the Department of Higher Education and Training under the regulations of the Act (DOE, 2007), and the corporate governance recommendations of best practice of King III (IOD, 2009). The questions were also based on the information obtained from the literature study and initial discussions with registrars.

The questionnaires were tested by a selected group of highly experienced people, consisting of academics, vice-chancellors and registrars. They all provided valuable input into the questionnaire design and content, resulting in a questionnaire designed to simplify completion and limit the time required for completion.

\subsection{Quantitative data control}

$\mathrm{HEl}$ registrars are considered to be highly respected and conscientious members of the academic community and, as such, it was accepted that they would exercise the necessary diligence and due care in the completion of the questionnaires. Accordingly, it was not considered necessary to test for prejudice or contradictions. The design and compilation of the questionnaires were also done with a high degree of caution to ensure that the questionnaires were set out logically and in a relevant manner, and accordingly easy to understand and complete.

The data was processed and analysed by the researchers and independently checked and reviewed for accuracy.

\subsection{Rigour and trustworthiness of qualitative data}

The qualitative element was included to improve understanding of university registrars' views on corporate governance practices at their HEls (Golafshani, 2003:600). Triangulation, both methodological and investigator, was used to increase the credibility and validity of the results reported in this article. Methodological triangulation requires the use of more than one research strategy, which for the purposes of this study consisted of the questionnaires (the quantitative element) as well as follow-up interviews (the qualitative element). The same information was thus uncovered from more than one vantage point, thereby confirming the credibility of the findings (Krefting, 1991:215). No blending of the quantitative and qualitative elements took place during data generation or analysis. During interpretation of data the findings from both qualitative and quantitative elements were merged to derive to the reported findings. Engaging in both quantitative and qualitative research by using questionnaires and follow-up interviews improved the validity and reliability of the study (Golafshani, 2003:604).

Investigator triangulation was achieved because two independent researchers, employed by different $\mathrm{HEls}$, conducted this study. Both were objective because they were not influenced by the study and did not influence the study, thereby promoting the conformability of the study (Krefting, 1991:217). They were present during the interviews and both recorded the events. The researchers discussed the findings, confirmed them with the interviewee, followed up contradictory findings and reached identical conclusions. The latter process contributed towards the dependability of the qualitative element in the study (Krefting, 1991:217). 


\subsection{Population and response rate}

This study is based on the views obtained from participating registrars of the 23 South African HEls. Sixteen completed questionnaires were received back, representing a response rate of $69.56 \%$, and one registrar returned the questionnaire and stated that because he/she was new to the position, he/she was not in a position to complete the questionnaire. The effective response rate, therefore, amounts to $73 \%$ (16/22). The response rate is considered acceptable if compared with the low response rates of empirical studies in general. This was found by Marx (2009:31) in a study of questionnaire response rates in master's and doctoral studies in the accounting and corporate governance-related fields to vary between $5 \%$ and $61 \%$ internationally and between $25 \%$ and to $38 \%$ in South Africa.

\section{RESEARCH FINDINGS AND INTERPRETATION}

This section presents the research findings based on $\mathrm{HEl}$ registrars' perceptions regarding corporate governance practices at their HEls. Both quantitative and qualitative elements were taken into account in the formulation of the findings. The majority of the reported findings relate to the quantitative element of the study.

TABLE 1: Corporate governance and the registrar

\begin{tabular}{|c|c|c|c|}
\hline & $N$ & $N / A$ & Mean \\
\hline Registrar's support for the concept of corporate governance & 15 & 1 & 4.4 \\
\hline \multicolumn{4}{|l|}{ Governance structures support for the registrar's role } \\
\hline Council & 16 & 0 & 4.7 \\
\hline The Vice-Chancellor & 16 & 0 & 4.6 \\
\hline The Audit Committee & 16 & 0 & 4.3 \\
\hline The Finance Committee & 16 & 0 & 4.3 \\
\hline The Risk Committee & 14 & 2 & 4.4 \\
\hline The Remuneration Committee (HR) & 16 & 0 & 4.0 \\
\hline Other related governance committees: & 11 & 5 & 4.6 \\
\hline \multicolumn{4}{|l|}{$\begin{array}{l}\text { Governance structure support for allowing the registrar to act } \\
\text { independently }\end{array}$} \\
\hline Council & 16 & 0 & 4.2 \\
\hline The Vice-Chancellor & 16 & 0 & 4.2 \\
\hline The Audit Committee & 16 & 0 & 4.2 \\
\hline
\end{tabular}

Source: Authors'analysis

Mean interpretation: mean $\geq 4.50$ very high level; $4.00 \leq$ mean $<4.50=$ high level; $3.00 \leq$ mean $<4.00=$ fairly high level; mean $=$ $3=$ neutral; $2.00 \leq$ mean $<3.00=$ fairly low level; mean $<2=$ low level

A five-point Likert scale was used where 1 'not at all' refers to the lowest point of the scale, 5 'very much' refers to the highest point of the scale and 3 is regarded as neutral. These findings are reported in accordance with mean scores of the results of the study. Information from open- 
ended questions or obtained during the follow-up interviews (the qualitative element of the study) are included in the discussions on the findings of the study.

TABLE 1 indicates a high level of support (mean $=4.40$ ) from participating registrars for the concept of corporate governance. Participating registrars perceived a high to very high level of support for their role from their HEl's governance structures (mean scores range from 4.0 to 4.7), with high levels of support from their HEl's councils, vice-chancellors and audit committees (mean $=4.2$ ) for their independence. These findings support the literature, as discussed in sections one and three, that the role of the registrar has evolved to that of an important corporate governance mechanism of HEls over and above the registrar's responsibilities relating to academic and student affairs.

Other committees of council, as listed in TABLE 1, identified by registrars who contribute to the corporate governance at their $\mathrm{HEls}$ are: executive committees of council, human resource committees, physical planning committees, governance committees and transformation oversight committees.

One of the participating registrars expressed serious reservations about the applicability of corporate governance in the higher education environment. According to this registrar a clear distinction should be made between a business environment, where sound corporate governance practices are justified, and $\mathrm{HEls}$, which should not be seen as businesses: 'an $\mathrm{HEl}$ is not a corporation'. As revealed by the literature, discussed in section 3, it would appear that this person felt that a university should still be managed in accordance with the traditional collegial self-governance model, in contrast to developments towards a model more closely aligned with business corporations. Other comments received from registrars included: 'there is a thin line between managing and governance' and 'at our institution there was a significant improvement in corporate governance in the past 5 years'.

TABLE 2 shows that participating registrars perceived that a fairly high level of reliance ('actual reliance') was placed on them by members of council (mean $=3.8$ and 3.9) and the vicechancellor (principal or rector) (mean $=3.7$ and 3.6) as to their understanding of the functioning of their $\mathrm{HEl}$ and their role in improving the effectiveness of their $\mathrm{HEl}$ 's corporate governance structures. Participating registrars also perceived that both members of council and the vice-chancellor (both means $=3.7$ ) deemed them to add a fairly high level of value to their HEl's corporate governance structures and ensured a high level of compliance (mean $=4.0$ and 4.1) with the corporate governance principles and practices applied by their HEls. The findings further indicated that participating registrars' perceptions of the extent of reliance placed on them by council members and the vice-chancellors of their HEls was in accord with their expectations (the ideal level of reliance).

Therefore, it appears that participating registrars regarded themselves as knowledgeable about the functioning of their $\mathrm{H} \varepsilon \mathrm{ls}$ and perceived that they made a positive contribution to HEIs' corporate governance practices by improving effectiveness and adding value and ensuring compliance with corporate governance principles. These findings support the literature on the evolving corporate governance role of the registrar. 
TABLE 2: Corporate governance reliance on the registrar

\begin{tabular}{|c|c|c|c|c|c|c|}
\hline & \multicolumn{3}{|c|}{ ACTUAL } & \multicolumn{3}{|c|}{$I D E A L$} \\
\hline & $N$ & $N / A$ & Mean & $N$ & $N / A$ & Mean \\
\hline \multicolumn{7}{|l|}{ Members of Council's reliance on the registrar: } \\
\hline To understand the functioning of the $\mathrm{HEl}$ & 16 & 0 & 3.8 & 16 & 0 & 3.8 \\
\hline $\begin{array}{l}\text { To improve the effectiveness of the corporate } \\
\text { governance structures of the } \mathrm{HEl}\end{array}$ & 16 & 0 & 3.9 & 16 & 0 & 3.9 \\
\hline $\begin{array}{l}\text { To improve the value added by corporate } \\
\text { governance structures of the } \mathrm{HEl}\end{array}$ & 15 & 1 & 3.7 & 15 & 1 & 3.7 \\
\hline $\begin{array}{l}\text { To ensure compliance with corporate governance } \\
\text { principles as applied to an } \mathrm{HEl}\end{array}$ & 15 & 1 & 4.0 & 15 & 1 & 4.0 \\
\hline \multicolumn{7}{|l|}{ The Vice-Chancellor's reliance on the registrar: } \\
\hline To understand the functioning of the $\mathrm{HEI}$ & 16 & 0 & 3.7 & 16 & 0 & 3.7 \\
\hline $\begin{array}{l}\text { To improve the effectiveness of the corporate } \\
\text { governance structures of the } \mathrm{HEl}\end{array}$ & 15 & 1 & 3.6 & 15 & 1 & 3.6 \\
\hline $\begin{array}{l}\text { To improve the value added by corporate } \\
\text { governance structures of the } \mathrm{HEl}\end{array}$ & 15 & 1 & 3.7 & 15 & 1 & 3.7 \\
\hline $\begin{array}{l}\text { To ensure compliance with corporate governance } \\
\text { principles as applied to an } \mathrm{HEl}\end{array}$ & 15 & 1 & 4.1 & 15 & 1 & 4.1 \\
\hline
\end{tabular}

Source: Authors'analysis

Mean interpretation: mean $\geq 4.50$ very high level; $4.00 \leq$ mean $<4.50=$ high level; $3.00 \leq$ mean $<4.00=$ fairly high level; mean $=$ $3=$ neutral; $2.00 \leq$ mean $<3.00=$ fairly low level; mean $<2=$ low level

TABLE 3: Governance structures and corporate governance at HEls

\begin{tabular}{llll}
\hline & $N$ & $N / A$ & MEAN \\
\hline Understand the concept of corporate governance at HEls & & & \\
Ministerial appointees of Council & 16 & 0 & 3.3 \\
The Vice-Chancellor & 16 & 0 & 4.9 \\
The Deputy Vice-Chancellor(s) & 16 & 0 & 4.3 \\
Members of Senate & 16 & 0 & 3.6 \\
Academic employees (other than Senate) serving on Council & 16 & 0 & 3.3 \\
Non-academic employees serving on Council & 16 & 0 & 2.9 \\
$\begin{array}{l}\text { Other independent members (e.g. legal advisors or business associates } \\
\text { of HEls) serving on Council }\end{array}$ & 16 & 0 & 3.6 \\
SRC members serving on Council & 16 & 0 & 2.8 \\
Adding value to the corporate governance of HEls & & &
\end{tabular}




\begin{tabular}{llll}
\hline & $N$ & $N / A$ & $M E A N$ \\
\hline Ministerial appointees of Council & 16 & 0 & 3.4 \\
The Vice-Chancellor & 16 & 0 & 4.6 \\
The Deputy Vice-Chancellor(s) & 16 & 0 & 4.1 \\
Members of Senate & 16 & 0 & 3.6 \\
Academic employees (other than Senate) serving on Council & 16 & 0 & 3.3 \\
Non-academic employees serving on Council & 16 & 0 & 3.3 \\
Other independent members (e.g. legal advisors or business associates & & & \\
of HEls) serving on Council & 16 & 0 & 3.7 \\
SRC members serving on Council & 16 & 0 & 2.8 \\
Contribute to the effectiveness of corporate governance of HEls & & & \\
Council & 16 & 0 & 4.1 \\
The Vice-Chancellor & 16 & 0 & 4.4 \\
The Senate & 16 & 0 & 3.7 \\
The Institutional Forum & 16 & 0 & 2.4 \\
SRC members serving on Council & 16 & 0 & 2.6 \\
The Audit Committee & 16 & 0 & 4.5 \\
The Finance Committee & 16 & 0 & 4.6 \\
The Risk Committee & 16 & 2 & 3.8 \\
The Remuneration Committee (HR) & 16 & 0 & 3.7 \\
\hline Source: Authors' analysis & & \\
\hline
\end{tabular}

\section{Source: Authors'analysis}

Mean interpretation: $\quad$ mean $\geq 4.50$ very high level; $4.00 \leq$ mean $<4.50=$ high level; $3.00 \leq$ mean $<4.00=$ fairly high level; mean $=3=$ neutral; $2.00 \leq$ mean $<3.00=$ fairly low level; mean $<2=$ low level

As far as understanding the concept of corporate governance at HEls went, TABLE 3 indicates that participating registrars perceived a very high level of understanding by vice-chancellors (mean $=4.9)$ and deputy vice-chancellors (mean $=4.3$ ), while the level of understanding of ministerial appointees was perceived to be at a fairly low level (mean $=3.3$ ). The notion that other council members, namely, senate members (mean $=3.6$ ), academic members (mean = 3.3), other independent council members (e.g. legal advisors or business associates) had a fairly high level of understanding (mean $=3.6$ ) of the concept of corporate governance at their $\mathrm{HEls}$ can be attributed to these council members' exposure to the South African business environment, while the level of understanding of non-academic employees (mean $=2.9$ ) and SRC members (mean $=2.8$ ) was perceived by participating registrars to be at a lower level. The limited understanding of $\mathrm{HEls}$ ' corporate governance by non-academic employees and SRC members was also concern raised during follow-up interviews and was identified as an area for improvement. An interviewee mentioned that members of council receive training on fundamental corporate governance principles and their application in the South African higher education sector but the impact of such training appeared questionable. It is, therefore, 
recommended that such training is related to actual circumstances, for example, presentations made to council could provide detail on the impact on the governance of the specific $\mathrm{HEl}$, and debates by council members could focus on the impact of decisions on the corporate governance of their institution.

Based on the perceptions of the participating registrars, the value added to the corporate governance at their HEls by council members varied. The findings, as reported in TABLE 3, indicated that participating registrars perceived their HEls' vice-chancellors (mean $=4.6$ ) and deputy vice-chancellors (mean $=4.1$ ) to add the highest level of value to the corporate governance of their $\mathrm{HEls}$. These perceptions agree with the perceived high level of understanding of the concept of corporate governance by these two parties (as reported above). A fairly high level of value is added, according to the perceptions of participating registrars, by ministerial appointees of council (mean $=3.4$ ), members of senate (mean = 3.6) and the other independent members (mean $=3.7$ ). For SRC members serving on council, the perceived added value was deemed to be fairly low (mean $=2.8$ ). This finding could be explained by the perceived fairly low understanding of the corporate governance concept by SRC members serving on council as explained during follow-up interviews. As indicated above, the aforementioned weakness should be considered and steps could be taken to ensure these council members are more informed about the concept of corporate governance and its impact on their $\mathrm{HEls}$, which could led to increased understanding and more value added.

Perceptions of participating registrars about the contributions made to the effectiveness of corporate governance practices at $\mathrm{HEls}$ by their vice-chancellor and senate members are in line with their perceived value added to the corporate governance of their HEls. A fairly low contribution (mean $=2.6$ ) to the effectiveness of corporate governance was perceived from SRC members serving on council, a view that agreed with the findings reported above and was also expressed during follow-up interviews. Participating registrars' perceptions indicated that their HEls' councils (mean $=4.5$ ) and their audit and finance committees (means $=4.1$ and 4.6 respectively) contributed to a high or even very high level of effectiveness thereto. The institutional forum was perceived by participating registrars to contribute a fairly low level (mean $=2.4$ ) to the effectiveness of the HEls' corporate governance. This is supported by the comments received and discussions held during follow-up interviews. An interviewee made the comment that 'an institutional forum (as one of the HEl's supreme governing bodies, responsible for ensuring good governance, quality, integrity, financial soundness, and the performance and reputation of each institution) as corporate governance mechanism is questionable'. This finding, together with the low mean score reported above, questions the role of the institutional forum as governance mechanism and supports an interviewee's comment that 'it could function more effectively without being burdened as a governing body of the HEl'. Although the findings of the study show that senate members were perceived to contribute a fairly high level (mean = 3.7) to the effectiveness of their HEls' corporate governance, qualitative comments received indicate that the senate fulfils an important role in this regard 'by holding executive to account in plenary meetings of senate'.

The chair of council fulfils a very important governance role at $\mathrm{HEls}$, similar to that of chairs of companies. King III emphasises the importance of such a person acting independently and providing overall leadership to the board. From the above findings, as reported in TABLE 4 , it is evident that most of the council chairs were considered by participating registrars to meet such requirements from a fairly high level to a high level (means range from 3.4 to 4.4 ). The lowest mean score was related to the independence of council chairs (mean $=3.4$ ) to hold such 
position. This finding is of concern because the chair of council should set the 'tone at the top' and guide councils independently.

TABLE 4: Chair of Council

\begin{tabular}{llll}
\hline & $N$ & $N / A$ & MEAN \\
\hline The Chair of the Council: & 16 & 0 & 3.4 \\
Acts independently & 16 & 0 & 4.4 \\
Has the academic qualifications to hold the position & 16 & 0 & 4.1 \\
Has the management skills to hold the position & 16 & 0 & 4.3 \\
Has the ability to effectively guide and direct Council & & & \\
\hline
\end{tabular}

\section{Source: Authors'Analysis}

Mean interpretation: $\quad$ mean $\geq 4.50$ very high level; $4.00 \leq$ mean $<4.50=$ high level; $3.00 \leq$ mean $<4.00=$ fairly high level; mean $=3=$ neutral; $2.00 \leq$ mean $<3.00$ = fairly low level; mean $<2=$ low level

Registrars were also asked to indicate whether the performance of their HEls' chair of council, vice-chancellor and deputy vice-chancellor(s) was annually assessed, and if so, to indicate the method in which it was assessed. Of the registrars surveyed, $38 \%$ indicated that the performance of their council chairs was assessed annually, while the remaining participating registrars indicated that both their vice-chancellor and deputy vice-chancellor(s) performance were annually assessed. The methods used for such assessments were evenly split between selfassessment by council members and assessment by the vice-chancellor. Respondents further indicated that combinations of these methods were used and that the latter were supplemented by external assessments and council performance instruments.

\section{TABLE 5: Functioning of council}

\begin{tabular}{|c|c|c|c|}
\hline & $N$ & $N / A$ & $M E A N$ \\
\hline \multicolumn{4}{|l|}{ The Council collectively: } \\
\hline Acts independently & 16 & 0 & 4.0 \\
\hline Acts objectively & 16 & 0 & 4.0 \\
\hline Acts in the best interest of my $\mathrm{HEl}$ & 16 & 0 & 4.3 \\
\hline $\begin{array}{l}\text { Has the right mix of experience through members to fulfil its role } \\
\text { effectively }\end{array}$ & 16 & 0 & 4.0 \\
\hline $\begin{array}{l}\text { Has the right mix of qualifications through members to fulfil its role } \\
\text { effectively }\end{array}$ & 16 & 0 & 3.9 \\
\hline Functions effectively & 16 & 0 & 4.0 \\
\hline Adds value to my $\mathrm{HEl} \mathrm{corporate} \mathrm{governance}$ & 15 & 1 & 4.0 \\
\hline
\end{tabular}

Source: Authors'analysis

Mean interpretation: $\quad$ mean $\geq 4.50$ very high level; $4.00 \leq$ mean $<4.50=$ high level; $3.00 \leq$ mean $<4.00=$ fairly high level; mean $=3=$ neutral; $2.00 \leq$ mean $<3.00=$ fairly low level; mean $<2=$ low level 
Of concern was the comment made by a few respondents that their $\mathrm{H} \varepsilon \mathrm{ls}$ were considering the abandonment of such assessments practices because of the low participation rate of council members. The latter, so-called 'poor responses by participants' was confirmed by an interviewee during a follow-up interview.

Participating registrars were requested to indicate whether they perceived that their HEls' council collectively met the requirements set out in TABLE $\mathbf{5}$. The findings reported in TABLE $\mathbf{5}$ indicate that participating registrars perceived their councils collectively to generally meet these requirements at a high level (a mean score of 4.0 or above was obtained for five of the seven listed requirements) or even at a very high level (a mean score of 4.3 was obtained for the statement that their $\mathrm{HEls}$ ' council collectively acted in the best interest of their $\mathrm{HEI}$ ). Participating registrars perceived that their $\mathrm{HEls}$ ' councils collectively, to a lesser extent, met the requirement of having the right mix of experience (mean $=4.0$ ) and qualifications (mean = 3.9) to fulfil their role effectively.

During the follow-up interviews the independence, objectivity and good faith of HEls' councils were discussed. Comments made by an interviewee during a follow-up interview further revealed concerns regarding the role of ministerial appointees and internal council members. The interviewee questioned the function of ministerial appointees: 'are they expected to report to the minister, or are they independent council members?', and asked whether they could still act with independence and objectively as well as in good faith, if their duty is merely that of a messenger to report to the minister. The interviewee further questioned the role of internal council members: 'are they representing the aspirations of their constituencies who elected them or are they acting as independent council members?'

Participating registrars were also questioned about whether they believed that council members should be remunerated. Only $31 \%$ of the participating registrars were of the view that council members should be remunerated, with very strong views expressed in the open-ended section of the question in the questionnaire and during follow up interviews. These include, inter alia, the following:

- 'Council membership should be disinterested public service by people of calibre. Fair pay for such people would be out of place for a university.'

- Rates for remuneration for council members should be stipulated by D0E.'

- 'Council member remuneration increases the right to performance reviews collectively and individually.'

- 'Remuneration for council members should be limited to reimburse direct expenses.'

From these findings and views expressed it is evident that remuneration of council members is a sensitive issue, and that it would probably be an aspect for each $\mathrm{HEl}$ to deal with individually.

The findings reported in TABLE $\mathbf{6}$ indicate the participating registrars' perception of the extent to which their HEls were complying with the abovementioned aspects in contrast with ideal compliance. In all instances the participating registrars perceived a gap between the current position and the ideal position, indicating areas for improvement. From these findings (with the exception of an HEl's official reporting responsibilities to stakeholders) it appears that participating registrars perceived their $\mathrm{HEls}$ to bear a higher level of reporting responsibilities (mean scores varied from 4.3 to 4.6 ) than what they accepted at the time of the study (mean scores varied from 2.8 to 3.8 ). 
TABLE 6 Social environmental and governance compliance

\begin{tabular}{|c|c|c|c|c|c|c|}
\hline \multirow{2}{*}{ My HEl is: } & \multicolumn{3}{|c|}{ ACTUAL CONDUCT } & \multicolumn{3}{|c|}{ IDEAL CONDUCT } \\
\hline & N & $N / A$ & $M E A N$ & $N$ & $N / A$ & $M E A N$ \\
\hline Complying with King III requirements & 16 & 0 & 3.4 & 16 & 0 & 4.3 \\
\hline Identifying its stakeholders & 16 & 0 & 3.8 & 16 & 0 & 4.6 \\
\hline Officially reporting to its stakeholders & 16 & 0 & 4.3 & 16 & 0 & 4.8 \\
\hline $\begin{array}{l}\text { Officially reporting on social aspects affecting the } \\
\mathrm{HEl}\end{array}$ & 16 & 0 & 3.8 & 16 & 0 & 4.6 \\
\hline $\begin{array}{l}\text { Officially reporting on ethical aspects affecting } \\
\text { the } \mathrm{HEl}\end{array}$ & 16 & 0 & 3.3 & 16 & 0 & 4.5 \\
\hline $\begin{array}{l}\text { Officially reporting on environmental aspects } \\
\text { affecting the } \mathrm{HEl}\end{array}$ & 16 & 0 & 2.8 & 16 & 0 & 4.4 \\
\hline
\end{tabular}

\section{Source: Authors'Analysis}

Mean interpretation: $\quad$ mean $\geq 4.50$ very high level; $4.00 \leq$ mean $<4.50=$ high level; $3.00 \leq$ mean $<4.00=$ fairly high level; mean $=3=$ neutral; $2.00 \leq$ mean $<3.00$ = fairly low level; mean $<2=$ low level

The reporting to stakeholders on social and environmental aspects is a strong recommendation of King II, and was carried forward into King III, which introduced the concept of corporate citizenship and emphasised the need for organisations to be responsible corporate citizens. A very positive and encouraging finding is the fact that the registrars perceived that their $\mathrm{HEls}$ should embrace such a reporting responsibility (mean $=4.4$ ), especially where the perceived practices was deemed by participating registrars to be at a fairly low level (mean $=2.8$ ).

Views expressed in the open-ended section of the questionnaire, which requested general comments, as well as those noted in follow up interviews, included inter alia, the following:

- 'King III is not applicable and is badly written. There are better codes for HEls to adhere to as much of King III is not applicable.'

- 'Reporting is done through the annual report and the report submitted to council on teaching, research and social responsiveness.'

- 'An HEl is not an [sic] corporation.'

- 'Stakeholders for a university not the same as stakeholders as envisaged by King III.'

- 'Placing all but commercially sensitive and private council and senate papers on a campus intranet enhances effective governance.'

- 'The link between King III and the provisions of the Higher Education Act in terms of higher education institutions should be explored.'

These views indicate that there is still uncertainty or at least lack of understanding regarding the importance and applicability of corporate governance principles and practices (and King III) to all organisations, including $\mathrm{HEls}$. The views also indicate a lack of understanding by some registrars of the fact that the role of $\mathrm{HEls}$ has changed, as discussed in sections one and three, from a purely academic institution under the collegial self-governance model to becoming more closely aligned with business corporations. 


\section{CONCLUSION AND AREAS FOR FURTHER RESEACH}

From the literature it is evident that the higher education environment has become more demanding over the years, resulting in HEls currently facing many challenges. This, in turn, has given rise to the need for sound management of these institutions and adherence to sound governance practices, which are becoming increasingly aligned with the corporate governance practices followed in the business environment. The role of the registrar has also evolved over the years from being an administrator of academic and student affairs to that of corporate governance custodian of $\mathrm{HEls.}$

The study focused on registrars' views of HEl corporate governance practices as well as their effectiveness at and value added to their institutions. These were obtained through a mixed research method, including elements of both quantitative and qualitative research. The quantitative element of the study was conducted by means of questionnaires, which included open-ended questions, while the qualitative element consisted of follow-up interviews.

The study revealed a high level of support for sound corporate governance practices at $\mathrm{HEls}$ in South Africa, and for the role of registrar, also enabling him/her to act independently. A fairly high level of reliance was perceived on the part of council members and vice-chancellors on the registrar as governance mechanism, which correlated well with the perceived expectations of council members and vice-chancellors in this regard. The findings of the study, therefore, lend support to the evolving corporate governance role of the registrar, over and above the traditional academic and student affairs responsibilities. Of concern is the possible lack of understanding revealed by some responding registrars regarding the changing role and challenges faced by HEls of today, and accordingly the need for and appropriateness of sound corporate governance practices at $\mathrm{HEls.}$

The findings of the study indicated that the understanding of corporate governance on the part of different council members was perceived to vary and that such understanding was perceived to relate to the value added and contributions made to HEls corporate governance effectiveness. Both quantitative and qualitative elements of the study supported the findings that SRC members serving on council were perceived to have a fairly low understanding of HEls' corporate governance and, therefore, only added limited value to the corporate governance of their $\mathrm{HEls}$ and contributed to its effectiveness at a fairly low level. It is recommended that SRC council members receive training on fundamental corporate governance principles in the South African higher education sector, which should be enforced by means of practical applications during council meetings. Presentations made to council could provide detail on the impact on the governance of the $\mathrm{HEl}$ and debates by council members could focus on the impact of decisions on the corporate governance of their institutions.

The role of the institutional forum as corporate governance mechanism was questioned. Given its main objective - which is to advise council broadly on issues affecting the institution in areas of implementation of legislation and national policy; race and gender equity; the selection of candidates for senior management positions; codes of conduct, mediation and dispute resolution; and the fostering of an institutional culture (Hall et al., 2002:20:37-38) - concern was expressed during an interview about whether it could function more effectively without being burdened as a governing body of the HEl. The finding reached from the quantitative element of the study, that the institutional forum contribution to the HEl's corporate governance effectiveness was deemed to be at a fairly low level of effectiveness, supported this concern. This is an area for future research, where the role, responsibilities, value and 
effectiveness of the institutional forums of $\mathrm{HEls}$ could be investigated. A qualitative research approach could be of much value in gaining insights from institutional forum members and other role-players through in-depth interviews.

Responding registrars expressed a high level of satisfaction with chairpersons of their HEls' councils in relation to their academic qualifications, management skills and abilities to guide and direct councils. A fairly high level of satisfaction was expressed by responding registrars on the independence of the chairperson of their HEls' councils. From the quantitative element of the study it further appeared that, although assessments were done on the performance of chair of councils, vice-chancellors and deputy vice-chancellor(s), various methods were used but that low response rates threatened the continuation of such practices. Although the responding registrars expressed a high degree of satisfaction with the collective functioning of the councils of their $\mathrm{HEls}$, some concerns were raised during the interviews regarding the role, independence, objectivity and good faith of ministerial appointees and internal council members. Perceptions based on the quantitative element and views expressed during the follow-up interviews did not agree on whether council members should be remunerated or not. Further research could be done, addressed at the chairpersons of council, as well as the vice-chancellors of the South African $\mathrm{HEls}$, to solicit their views regarding corporate governance practices and effectiveness at their institutions. In particular, the role of SRC council members, institutional forums, ministerial appointees and internal council members in $H E l$ corporate governance could be considered. Other aspects such as the assessment of the performance of council members and their remuneration could also be included in the study. Such a study could also be extended to private South African HEls in order to assess the current state of corporate governance, value added and corporate governance effectiveness at such institutions.

The findings of both the quantitative and qualitative elements of the study revealed that participating registrars supported very high levels of compliance with King III and fully support the reporting responsibility of their $\mathrm{HEls}$ to stakeholders on social, ethical and environmental aspects. However, the participating registrars perceived the actual compliance of their $\mathrm{HEls}$ with King III and their adherence to the aforementioned reporting responsibilities to be at a much lower level. These findings should be investigated further to determine practices and procedures that HEls should follow to ensure a high level of compliance with King III. The compliance status of public and private HEls in South Africa should also be investigated with the aim of making recommendations to increase compliance levels. A similar approach could be followed with regard to social, ethical and environmental reporting responsibilities of HEls. Further research could determine the extent of such responsibilities and to formulate guidelines for $H E l s$ to disclose social, ethical and environmental matters in their reports.

\section{LIST OF REFERENCES}

Anonymous. (2010). What is a registrar? North Central College. [Online] Available from: http://northcentralcollege.edu/x5936.xml (Accessed 17 November 2010).

Arnold, $\varepsilon$. (2006). Facilitating university sustainability through decision-orientated financial reporting. Unpublished MEd mini-thesis. Cape Town: University of the Western Cape.

Bargh, C., Scott, P. \& Smith, D. (1996). Governing universities: Changing the culture? Ballmoor: Open University Press. 
Belloc, B. (2003). Incentives and accountability: Instruments of change in higher education. Higher Education Management and Policy, 15(1), pp. 23-41.

Boyce, G. (2002). Now and then: Revolutions in higher learning. Critical Perspectives on Accounting, 13, pp. 575-601.

Brown, R. (2001). The governance of the new universities: Do we need to think again? Perspective, 5(1), pp. 42-47.

Brookes. (2010). Academic registry. [Online] Available:

http://www.brookes.ac.uk/services/asd/registry (Accessed 17 November 2010).

Considine, M. (2000). APSA Presidential Address 2000: The tragedy of the common-rooms? Political science and the new university governance. Australian Journal of Political Science, 36, pp. 145-156.

Council for Higher Education ( $\mathrm{CHE}$ ). (2000). Shape and size of higher education task team. Towards a new higher education landscape: Meeting the equity, quality and social imperatives of South Africa in the $21^{\text {st }}$ century. Pretoria: South Africa.

Council for Higher Education (CHE). (2009a). Report of the Council on Higher Education's Consultative Conference, 2009. [Online] Available: http://www.che.org.za/documents/d000203/. (Accessed 15 October 2010).

Council for Higher Education ( $\mathrm{CHE}$ ). (2009b). The Response of the Council on Higher Education to the report of the Ministerial Committee on Transformation and Social Cohesion and the Elimination of Discrimination in Public Higher Education Institutions. [Online] Available: http://www.che.org.za/documents/d000202/. (Accessed 15 October 2010).

Council for Higher Education (CHE). (2009c). The state of higher education in South Africa. Higher Education Monitor, 8: October. South Africa.

Dearlove, J. (2002). A continuing role for academics: The governance of UK universities in the postDearing era. Higher Education Quarterly, 56(3), pp. 257-275.

Department of Education (DOE). (2007). Implementation Manual for Annual Reporting by Higher Education Institutions (second volume). Pretoria: Department of Education.

De Groof, J.D., Neave, G. \& Svec, J. (1998). Democracy and Governance in Higher Education. Legislative Reform Programme for Higher Education and Research Council of Europe. The Hague, Netherlands: Kluwer Law International.

Diamond, M. \& DeBlois, P. B. (2007). Accountability and academic innovation: Don't forget the registrar. Inside Higher Education. [Online] Available:

http://www.thenationalacademy.org/readings/accountability.html. (Accessed 17 November 2010).

Dill, D. (2001). The regulation of public research universities: Changes in academic competition and implications for university autonomy and accountability. Higher Education Policy, 14(1), pp. 21-35.

Enders, J. (2004). Higher education internationalisation and the nation-state: Recent developments in governance theory. Higher Education, 47, pp. 361-382.

Ferreira, M. (2003). A framework for continuous improvement in the South African higher education sector. Unpublished DPhil thesis. Pretoria: University of Pretoria.

Geuna, A. \& Muscio, A. (2009). The governance of university knowledge transfer: A critical review of the literature. Springer Science+Business Media B.V. 
Golafshani, N. (2003). Understanding reliability and validity in qualitative research. The Qualitative Report, 8(4), pp. 597-607.

Hall, M., Symes, A. \& Luescher, T.M. (2002). Governance in South African higher education: Research report prepared for the Council Of Higher Education. South Africa: CHE.

Harman, K. \& Treadgold, \&. (2007). Changing patterns of governance for Australian universities. Higher Education Research \& Development, 26(1), pp. 13-29.

Henkel, M. (1997). Academic values and the university as corporate enterprise. Higher Education Quarterly, 51(2), pp. 134-143.

Henning, E., Van Rensburg, W. \& Smit, B. (2004). Finding your way in qualitative research, $2^{\text {nd }}$ edition. Pretoria: Van Schaik Publishers.

Huisman, J. \& Currie, J. (2004). Accountability in higher education: bridge over troubled water. Higher Education, 48, pp. 529-551.

Hutton, W. (1999). The development of performance indicators required for effective management of South African universities and technikons. Unpublished MBA thesis. Port Elizabeth Technikon.

Institute of Directors (loD). (2009). King report on corporate governance for South Africa.

Johannesburg: Institute of Directors in Southern Africa.

Kezar, A. \& Eckel, P. D. (2004). Meeting today's governance challenges: A synthesis of the literature and examination of a future agenda for scholarship. The Journal of Higher Education, 75(4), pp. 371399.

Krefting, L. (1991). Rigor in qualitative research: The assessment of trustworthiness. The American Journal of Occupational Therapy, 45(3), pp. 214-222.

Kulati, T. (2000). Governance, leadership and institutional change in South African higher education: Grappling with instability. Tertiary Education and Management, 6, pp. 177-192.

Kulati, T. (2003). From protests to challenge: Leadership and higher education change in South Africa. Tertiary Education and Management, 9, pp. 13-27.

Lazaretti, L. \& Tavoletti, S. (2006). Governance shifts in higher education: A cross-national comparison. European Educational Research Journal, 5(1), pp. 18-37.

Leo, T. (2003). The development of a financial performance measurement framework for South African education institutions. Unpublished MBA thesis. Port Elizabeth Technikon.

Lockwood, G. (1979). The role of the registrar in today's university. Higher Education, 8, pp. 299-320.

Marx, B. (2007). Corporate governance practices at higher education institutions in South Africa. Journal of Economic and Financial Sciences, 1(2), pp. 105-122.

Marx, B. (2009). Business leaders and the completion of questionnaires. Accountancy SA, 31(June), p. 12.

Mills, M.R. (2007). Stories of politics and policy: Florida's higher education governance reorganization. The Journal of Higher Education, 78(2), pp. 162-189.

Ministry of Education (MoE). (2006). Ministerial statement on higher education funding: 2006/7 to 2008/9. [Online] Available from:

http://www.dhet.gov.za/LinkClick.aspx?fileticket=1pKcrKHM4Kw\%3d\&tabid=417\& mid $=1221$.

(Accessed 13 April 2011). 
Mok, K. (2003). Globalism and higher education restructuring in Hong Kong, Taiwan and Mainland China. Higher Education Research \& Development, 22(2), pp. 117-129.

Nagy, J. \& Robb, A. (2008). Can universities be good corporate citizens? Critical Perspectives on Accounting, 19, pp. 1414-1430.

Naidoo, M. (2006). An analysis of the financial management systems, cost management systems and decision making systems of private higher education institutions in South Africa from 1990 to 2005. Unpublished DPhil thesis. Potchefstroom: University of the North West.

Pearsall, J. (2002). The concise Oxford English dictionary. $10^{\text {th }}$ edition, revised. New York: Oxford University Press.

Pelham, D., Preswood, K. \& Roof, J. (n.d.). The changing role of the community college registrar: Would your president rehire you? [Online] Available from: http://www.aacrao.org/sandiego/tuesday/T6_544.pdf. (Accessed 15 April 2011).

Peterson, M.W. (1986). Ashe reader on organization and governance in higher education. Ashe Rader Series. $3^{\text {rd }}$ edition. Lexington, Massachusetts: Ginn Press.

Pope, M.L. (2004). A conceptual framework of faculty trust and participation in governance. New Direction for Higher Education, 127, pp. 75-84.

PricewaterhouseCoopers (PWC). (2009). King's Counsel: King III - a higher education perspective. South Africa: Corporate Governance Series.

Rees, R. (2009). The role of the university registrar in promoting inclusion. The International Journal of Diversity in Organisations, Communities and Nations, 9(2), pp. 157-165.

Republic of South Africa (RSA). (1997). Higher Education Act No 101 of 1997. Government Gazette No 18515, Notice 1655, 19 December 1997. Pretoria: Government Printer

Republic of South Africa (RSA). (2003). Regulations for Annual Reporting by Higher Education Institutions. Government Gazette No 25407, Volume 458, August 2003. Pretoria: Government Printers.

Republic of South Africa (RSA). (2007). Regulations for Annual Reporting by Higher Education Institutions. Government Gazette No 30132. Pretoria: Government Printers.

Salter, B. \& Tapper, T. (2002). The external pressures on the internal governance of universities. Higher Education Quarterly, 56(3), pp. 245-256.

Shattock, M. (2002). Re-balancing modern concepts of university governance. Higher Education Quarterly, 56(3), pp. 235-244.

Smout, M. \& Stephenson, S. (2002). Quality assurance in South African higher education: A new beginning. Quality in Higher Education, 8(2), pp. 197-206.

Taylor, J. (2003). Sticks and carrot: The effectiveness of government policy on higher education in England since 1979. Higher Education Management and Policy, 15(1), pp. 91-103.

Van Niekerk, M.M. (2005). Transformation leadership at a higher education institution. Unpublished MA thesis. Pretoria: University of South Africa.

Whitchurch, C. (2004). Administrative managers - a critical link. Higher Education Quarterly, 58(4), pp. 280-298.

Wolhurter, C., Van der Walt, H., Higgs, L. \& Higgs, P. (2007). Die akademiese professie in Suid-Afrika se belewing van die huidige rekonstruksie van die samelewing en die hoër onderwys. Tydskrif vir Geesteswetenskappe, 47(4), pp. 501-515. 